\title{
NEKA ISKUSTVA MAĐARSKIH \\ KNJIŽNIČARA U PRIKUPLJANJU STATISTIČKIH \\ PODATAKA O KNJIŽNICAMA
}

\author{
THE EXPERIENCE OF HUNGARIAN LIBRARIANS \\ IN COLLECTING STATISTICAL DATA ON LIBRARIES
}

\author{
Ágnes Fülöp \\ Központi Statisztikai Hivatal Könyvtár \\ (Hungarian Central Statistical Office Library) \\ Budimpešta \\ agnes.fulop@ksh.hu
}

UDK / UDC 027(439):519.2

Stručni rad / Professional paper

Prihvaćeno / Accepted: 24. 5. 2017.

\section{Sažetak}

Druga polovica 20. st. iz više je razloga donijela niz promjena u mađarske knjižnice. Osim onih tehnoloških, one su se odnosile i na potrebe planiranja djelatnosti, strateško ulaganje i pravdanje troškova te na raspolaganje znanjima o kvaliteti pruženih resursa i usluga, što je sve naglasilo potrebu prikupljanja statističkih podataka i mjerenja uspješnosti knjižnica.

$\mathrm{S}$ vremenom, ti su statistički podaci, uz tradicionalne parametre veličine, opsega, stanja i starosti građe, financijskih sredstava te broja i spreme zaposlenika, počeli uključivati i pokazatelje aktivnosti knjižnica, zadovoljstva korisnika i najšireg učinka knjižnica na korisničku i širu društvenu zajednicu.

Rad prikazuje iskustva mađarskih knjižničara u prikupljanju statističkih podataka o knjižnicama i knjižničnoj djelatnosti.

Ključne riječi: knjižnična statistika, prikupljanje statističkih podataka o knjižnicama, mađarske knjižnice

Vjesnik bibliotekara Hrvatske 60, 1(2017), 173-182

ISSN 0507-1925

(C) VBH 2017. 


\section{Summary}

The second half of the $20^{\text {th }}$ century brought many changes to Hungarian libraries. Besides the new technological improvements, the changes have been introduced into planning of library activities, strategic investments, costs justification, and providing data on the quality of library resources and services, all of which emphasized the importance of collecting statistical data for library performance evaluation.

Over the years, the library statistical reports have introduced new indicators of library performance like user satisfaction and library impact on the community, which were added to the traditional evaluation parameters of size, scope, status and age of library materials, financial resources, the number of employees and their education levels.

The paper presents the experience of Hungarian librarians in collecting data in the field of library statistics.

Keywords: library statistics; collecting statistical data on libraries; Hungarian libraries

\section{Neke povijesne činjenice}

U Mađarskoj se počeci prikupljanja statističkih podataka o knjigama i knjižnicama čvrsto vezuju uz Knjižnicu Središnjega statističkog zavoda Mađarske. Središnji statistički zavod Mađarske i njegova knjižnica osnovani su 1867. godine na temelju molbe Károlya Keletija ${ }^{1}$ s ciljem prikupljanja statističkih podataka o knjižničnoj i izdavačkoj djelatnosti na teritoriju Mađarske.

Krajem 1920-ih godina Središnji statistički zavod Mađarske počeo je prikupljati podatke o kulturnim djelatnostima i ustanovama. Već od 1949. godine sustavno se prikupljaju usporedivi podaci o djelovanju knjižnica. Od 1968. godine zadatkom prikupljanja statističkih podataka o knjigama i knjižnicama bavi se Nacionalna knjižnica Széchényi (mađ. Országos Széchényi Könyvtár; eng. National Széchényi library), u čije su registre od 1998. godine uključene sve javne knjižnice u Mađarskoj.

Do kraja 20. stoljeća statistički podaci uključivali su tradicionalne parametre: prostor, broj i spremu zaposlenika, podatke o zbirkama itd. Današnji podaci daleko su opsežniji i kompleksniji. Posebna statistička izvješća sastavljaju se u mađarskom Ministarstvu kulture na temelju podatka Nacionalne knjižnice Széchényi (OSAP 1442) i statističkih podataka o kulturnim djelatnostima iz Središnjega statističkog zavoda Mađarske.

1 Károly Keleti (1833.-1892.), mađarski ekonomist i političar, utemeljitelj suvremene mađarske statistike. 


\section{Statistički podaci o mađarskim knjižnicama}

Krećući od najšireg europskog prostora kulture i kulturnih djelatnosti, u radu se ponajprije iznose statistički podaci koje je pomoću anketa i intervjua Eurobarometra prikupila Europska komisija. Već iz sl. 1, koja donosi prikaz vrijednosti nekih pokazatelja relevantnih za pozicioniranje i tumačenje aktualnog stanja knjižnične djelatnosti u Mađarskoj i Europskoj uniji, a u kontekstu pristupa i sudjelovanja u kulturnim aktivnostima, mogu se prepoznati bit i svrha knjižnične statistike, a to su posjedovanje podataka o knjižničnim resursima i uslugama, mogućnost analize i planiranja djelatnosti te usmjeravanje operativnog i strateškog ulaganja i odlučivanja.

Sl. 1 prikazuje rezultate istraživanja Europske komisije o pristupu i sudjelovanju u kulturnim aktivnostima u 2013. godini, a među njima i o čitanju knjiga te broju posjeta javnim knjižnicama, pri čemu se rezultati prikazani svjetlijom nijansom boje odnose na Mađarsku, a oni prikazani tamnijom nijansom boje odnose se na ukupne prosječne vrijednosti Europske unije. ${ }^{2}$

Istraživanje je provedeno metodom intervjua utemeljenog na upitniku koji se sastojao od 6 višestrukih pitanja, a u Mađarskoj se provodilo od 27. travnja 2013. do 12. svibnja 2013. na uzorku od 1033 ispitanika. ${ }^{3}$

Za knjižničnu djelatnost i njezino pozicioniranje u kontekstu pristupa i sudjelovanja u kulturnim aktivnostima relevantni su rezultati koji se odnose na dva pokazatelja: prvo, čitanje knjiga, te drugo, odlazak u javnu knjižnicu.

Rezultati zahtijevaju pozornost i potiču na poduzimanje mjera kojima bi se djelovalo na uočene aktualne nepovoljne trendove. Naime u obje stavke zamjećuje se pad vrijednosti u odnosu na vrijednosti dobivene u prethodnom istovrsnom istraživanju provedenom 2007. godine, i to kako u čitavoj Europskoj uniji tako i u Mađarskoj. U Europskoj uniji pad vrijednosti koji se vezuje uz čitanje knjiga iznosi 3\%, dok je u Mađarskoj veći i iznosi 18\%. Za odlazak u javnu knjižnicu pad vrijednosti na razini Europske unije iznosi 4\%, dok u Mađarskoj iznosi $14 \%$.

\footnotetext{
2 European Commission. cultural access and participation : Eurobarometer 79.2 : results for Hungary. Bruxelles, 2013. Str. 1. Dostupno na http://ec.europa.eu/commfrontoffice/publicopinion/archives/ebs/ebs 399 fact hu en.pdf [citirano: 2017-02-09].

3 U istraživanju su sveukupno sudjelovala 26563 ispitanika iz svih zemalja članica Europske unije.
} 


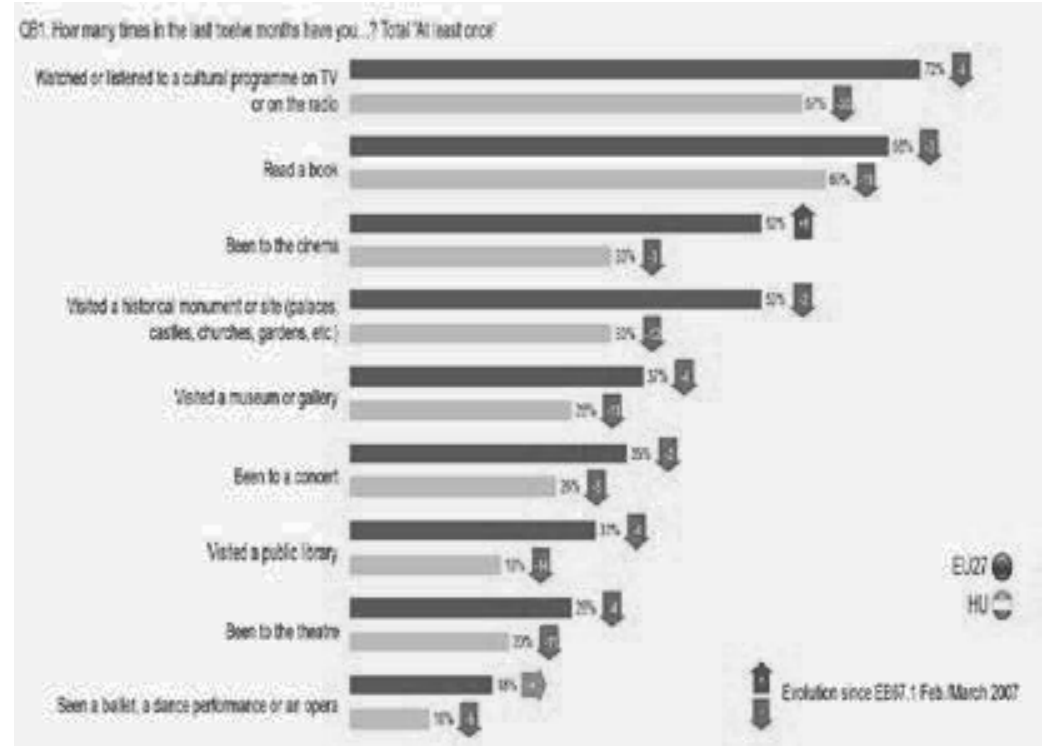

Slika 1. Pristup i sudjelovanje u kulturnim aktivnostima u Mađarskoj u 2013. godini, prema izvješću Eurobarometra

Krećući od utvrđenih vrijednosti, no sada u kontekstu isključivo knjižnične djelatnosti, i to samo u Mađarskoj, korisno je utvrditi da je, prema podacima iz statističkih izvješća o knjižnicama i arhivima Središnjega statističkog zavoda Mađarske, u 2015. godini u Mađarskoj djelovalo 13 nacionalnih i središnjih specijalnih knjižnica, 4029 narodnih knjižnica, 746 specijalnih knjižnica te 2981 školska knjižnica. ${ }^{4}$

Uz podatke o vrsti i broju knjižnica, Središnji statistički zavod Mađarske kao relevantne prikuplja i podatke koji se odnose na ukupan broj jedinica knjižnične građe, broj registriranih korisnika knjižnica, broj posjeta knjižnicama, broj ostvarenih kontakata s knjižnicama na daljinu (telefonski pozivi, e-pošta, korištenje online kataloga i mrežnih stranica knjižnica) te broj posuđenih jedinica knjižnične građe.

Iz statističkih podataka o posudbi građe u javnim knjižnicama u Mađarskoj u razdoblju od 2000. do 2015. godine prikazanih na sl. $2^{5}$ vidljivo je da je u 2015. godini zabilježen osjetan porast registriranih korisnika javnih knjižnica u odnosu

4 Libraries, archives (1990-) : STADAT [citirano: 2017-02-09]. Dostupno na https://www.ksh. $\mathrm{hu} / \mathrm{docs} / \mathrm{eng} / \mathrm{xstadat} / \mathrm{xstadat}$ annual/i_zkz002a.html.

5 Hungary in figures : 2015. Budapest : Hungarian Central Statistical Office, 2016. Str. 21. [citirano: 2017-02-09]. Dostupno na http://www.ksh.hu/docs/hun/xftp/idoszaki/hif/hungary_in_ figures_2015.pdf. 
na prethodne godine, dok je broj posuđenih jedinica građe u 2015. godini osjetno niži od vrijednosti iz 2000. godine, te da se radi o kontinuiranom padu, koji je donekle ublažen rastom vrijednosti tek u 2015. godini.

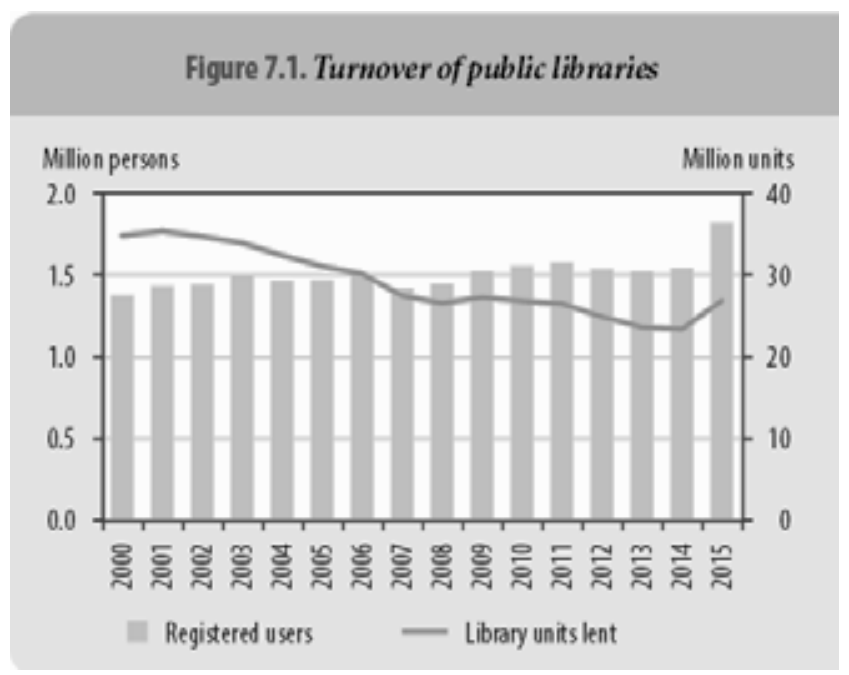

Slika 2. Posudba u mađarskim javnim knjižnicama u razdoblju od 2000. do 2015. godine

Usporedni prikaz spomenutih relevantnih pokazatelja knjižnične djelatnosti u Mađarskoj u razdoblju od 2000. do 2015. godine vidljiv je na sl. 3. ${ }^{6}$ Iz prikaza je moguće utvrditi i pratiti trendove prema vrsti knjižnica.

Tako u naznačenom 15-godišnjem razdoblju statistički podaci za nacionalne i središnje specijalne knjižnice ukazuju na rast ukupnog broja jedinica knjižnične građe i rast broja posuđenih jedinica knjižnične građe te, istovremeno, na pad broja knjižnica i pad broja registriranih korisnika knjižnica. Narodne knjižnice $\mathrm{u}$ istom razdoblju bilježe rast broja knjižnica, rast broja registriranih korisnika knjižnica i rast ukupnog broja jedinica knjižnične građe, ali i pad broja posuđenih jedinica knjižnične građe. Statistički podaci za specijalne knjižnice ukazuju na pad broja specijalnih knjižnica (u 2015. godini gotovo na polovinu broja knjižnica iz 2000. godine), pad ukupnog broja jedinica knjižnične građe te pad broja posuđenih jedinica knjižnične građe, uz rast broja registriranih korisnika knjižnice. Školske knjižnice $u$ istom razdoblju bilježe pad broja knjižnica te pad broja posuđenih jedinica knjižnične građe, uz istovremeni rast ukupnog broja jedinica knjižnične građe.

6 Magyar Statisztikai Évkönyv = Statistical yearbook of Hungary : 2015. Budapest: Központi Statisztikai Hivatal, 2016. Str. 139. 
Iz prikazanih vrijednosti vidljivo je da je svaka od analiziranih vrsta knjižnica bilježila drugačiji trend, koji se može pratiti i analizirati upravo na temelju statističkih podataka koje su sve javne mađarske knjižnice bile dužne dostavljati Središnjem statističkom zavodu Mađarske.

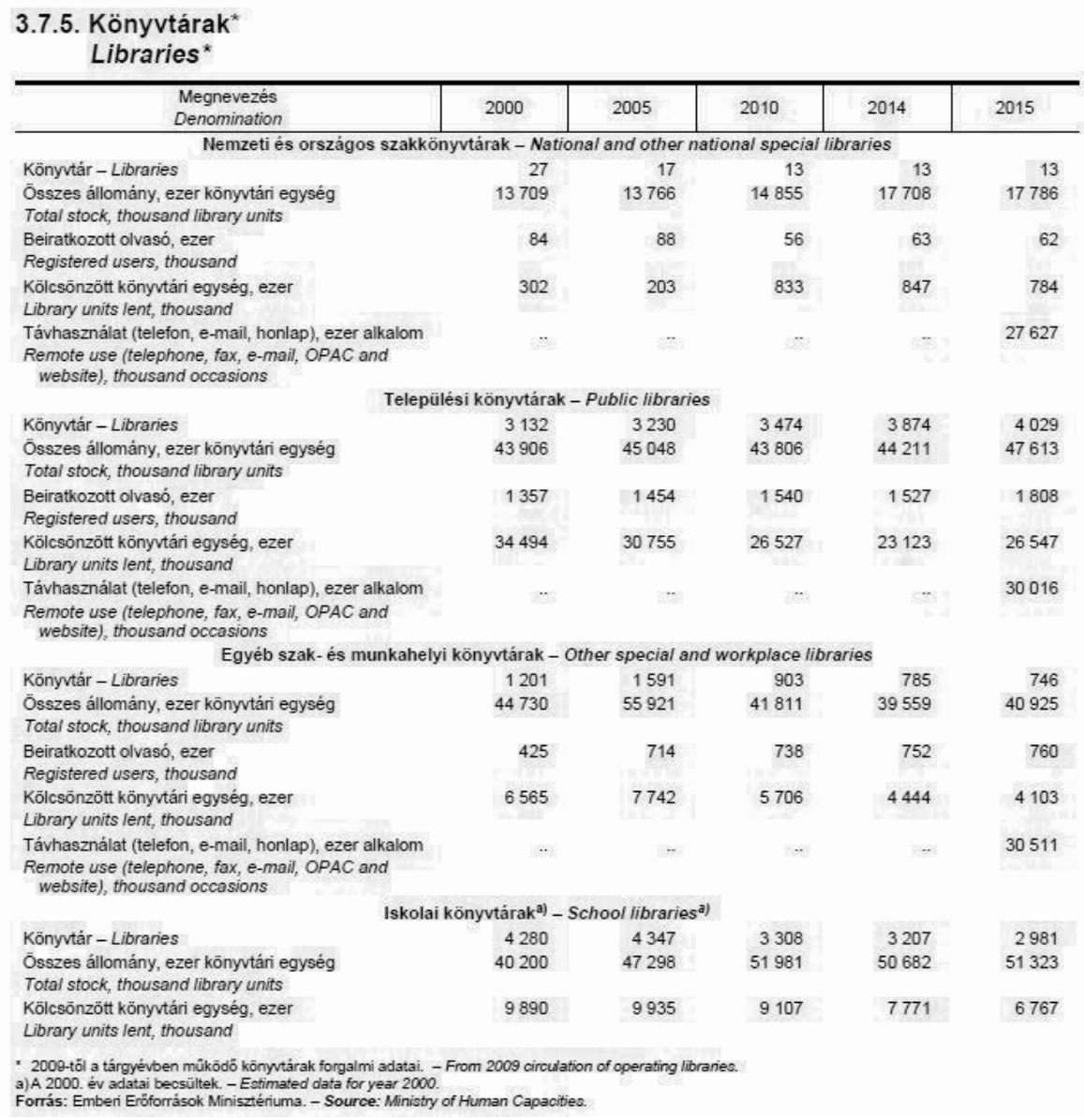

Slika 3. Statistički podaci o mađarskim knjižnicama za razdoblje od 2000. do 2015. godine

\section{Svrha i relevantnost knjižnične statistike u Mađarskoj}

Svrha službene statistike jest nepristrano, organizirano, sustavno i svrhovito prikupljanje i diseminacija statističkih podataka o državi, gospodarstvu, javnim djelatnostima ili događajima koji se mogu mjeriti statističkim metodama ili po- 
dacima. U tom kontekstu, Keletijev rad i osnutak Središnjega statističkog zavoda Mađarske za mađarske su prilike označili epohalni iskorak, pri čemu je bilo važno da se, uz zanimanje za bogatstvo zemlje, naroda i gospodarstva, interes za prikupljanje statističkih podataka usmjerio i prema kulturnim i obrazovnim djelatnostima, među kojima i prema mađarskom knjižničarstvu.

Danas se, nasuprot općeprihvaćenoj važnosti statistike, među mađarskim knjižničarima sve češće postavlja pitanje njezine svrhe i korisnosti. Naime statistika knjižnične djelatnosti informira o promjenama i tendencijama djelatnosti i sustava, pod uvjetom da su podaci koji se prikupljaju točni, pouzdani, sustavni i usporedivi, kako bi se knjižnična djelatnost mogla strateški osmišljavati, planirati, organizirati i financirati te provoditi donošenjem ispravnih operativnih i strateških odluka.

Usprkos razvoju metodologije prikupljanja i obrade statističkih podataka, sustavnom provođenju statističkih istraživanja te uključivanju sve većeg broja kvalificiranih aktera u prikupljanje statističkih podataka o knjižničnoj djelatnosti (Nacionalna knjižnica Széchényi, Ministarstvo kulture, Središnji statistički zavod Mađarske), ipak se iz knjižnične prakse sve više postavljaju pitanja stvarnog smisla i koristi od knjižnične statistike, budući da raste broj onih koji zahtijevaju da knjižnice prikupljaju i daju svoje statističke i druge podatke, a knjižnice same često ne vide pozitivne učinke sudjelovanja u tim aktivnostima.

Usto, knjižničari skreću pozornost i na probleme u metodologiji prikupljanja statističkih podataka o knjižničnoj djelatnosti, posebice njezinoj nesuvremenosti, neusklađenosti sa zahtjevima suvremenog tehnološkog okoliša, te upozoravaju na nedovoljno razumijevanje posebnosti knjižnične djelatnosti. Evidentan problem predstavlja i nepotpunost statističkih podataka u prikupljenim izvješćima.

\section{Neka iskustva i uočeni problemi knjižnične statistike u Mađarskoj}

Da bi postupak statističke obrade podataka bio valjan, mora se temeljiti na jasno definiranim pojmovima, što zahtijeva dobro poznavanje različitih struka, područja, tematika i metodologija, te u skladu s njima i na odabiranju relevantnih i usporedivih pokazatelja. Stoga je za ilustraciju dijela metodoloških problema koji proizlaze iz pogrešnog odabira pokazatelja, do kojega dolazi uslijed nepoznavanja posebnosti knjižnične djelatnosti, korisno prisjetiti se da su primjerice do 2015. godine mađarska kazališta prema prikupljenim statističkim podacima bilježila daleko veći broj posjeta nego knjižnice, jer su se u slučaju kazališta prikupljali podaci o broju prodanih ulaznica, dok su se u slučaju knjižnica prikupljali podaci o broju upisanih korisnika, što danas smatramo primjerom uspoređivanja relevantnih, ali raznorodnih i stoga neusporedivih podataka.

No govoreći o metodologiji, problemi se javljaju već na razini definiranja pojmova, pri čemu odgovornost nije samo na onima koji prikupljaju statističke podatke, jer postoji mogućnost da i sami knjižničari istu knjižničnu stvarnost definiraju i 
interpretiraju različito. Tako primjerice iz statističkih izvješća proizlazi da knjižnica „Szabó Ervin” iz Budimpešte sebe smatra jednom knjižnicom s 49 ogranaka koji rade u mreži, premda su neki od tih ogranaka veći i od nekih narodnih knjižnica. Istovremeno, u području specijalnog knjižničarstva, prema istim izvješćima knjižnicom se smatra i po nekoliko polica u prostorima sudova ili liječničkih ordinacija. Doista, smatra li se knjižnicom jedna prostorija u kakvom selu, koja je za korisnike otvorena jednom tjedno? Nadalje, što se knjižničnoga prostora tiče, kako evidentirati prostor spremišta, koje je nerijetko ne samo dislocirano nego i vrlo udaljeno od svoje knjižnice? Jednako tako, i kulturni programi koje knjižnice ostvaruju otvaraju problem raznovrsnih interpretacija i mogućnosti evidentiranja za potrebe prikupljanja statističkih podataka.

Što se nesuvremenosti statistike o knjižničnoj djelatnosti tiče, iz sl. 3 vidljivo je da podatke o broju posjeta knjižnici i broju ostvarenih kontakata s knjižnicama putem interneta Središnji statistički zavod Mađarske prikuplja tek od 2015. godine, premda su ih knjižnice, dakako, ostvarivale i ranije.

Pitanje digitalizacije naglasilo je izostanak planskog, jednoobraznog i koordiniranog pristupa, kao i nedostatak strategije u statističkom prikupljanju podataka o knjižničnoj djelatnosti, što rezultira nepostojanjem odgovarajućeg registra o dosad digitaliziranoj građi, ali i neprepoznavanjem usluga koje suvremene knjižnice pružaju od strane onih koji prikupljaju statističke podatke o knjižničnoj djelatnosti. Elektronički dokumenti i dinamičnost elektroničkoga okoliša uopće unijeli su niz nepoznanica kojima statistička izvješća i dalje nisu našla prikladan pristup, te se i dalje teško prikupljaju podaci o elektroničkim dokumentima, pristupima bazama podataka, repozitorijima, digitaliziranim dokumentima, zbog još uvijek nejasnih definicija pojmova i mjerila (vrijeme, transakcije, pristupi, korištenje, aktivnosti itd.).

Pitanje knjižnične statistike posebno je naglašeno od devedesetih godina 20. stoljeća naovamo, usporedno s društvenim i ekonomskim promjenama, koje inzistiraju na utvrđivanju potreba, pravdanju troškova i dokazivanju uspješnosti djelatnosti i ustanova, pa raste važnost pokazatelja za vrednovanje djelatnosti koji se temelje na aktivnostima knjižnica, zadovoljstvu korisnika te najširem učinku knjižnica na korisničku i širu društvenu zajednicu. To je nova zadaća koju knjižnična statistika dobiva u dokumentiranju učinka knjižnica i njihove uloge u mađarskom društvu, a knjižnična statistika tek treba dokazati da je dorasla toj, danas najvažnijoj, zadaći.

Kao primjer pozitivnog utjecaja knjižnične statistike korisno je prisjetiti se nepovoljnog trenda u mađarskom specijalnom knjižničarstvu, koji se odvijao krajem 20. stoljeća, a bio je rezultat specifičnih, tranzicijskih događanja i okolnosti, u prvom redu privatizacije niza tvornica, tvrtki itd. koje su unutar svojih organizacijskih jedinica imale i knjižnice. ${ }^{7}$ Najvećim su dijelom u tim godinama, usprkos

Cserta, Orsolya. A kulturális piac (ki)alakulása Magyarországon. // Statisztikai Szemle 5-6(2002), str. 589. [citirano: 2017-02-09]. Dostupno i na http://www.ksh.hu/statszemle_archive/2002/2002_05-06/2002_05-06_577.pdf. 
nizu napora, te knjižnice naposljetku bile ugašene (v. sl. 3), dok je njihov manji broj doživio neku vrstu preobrazbe, pri čemu su najvećim dijelom postale narodne knjižnice. Mjera koja je tih godina bila uvedena u mađarske knjižnice i dala pozitivan ishod tim događanjima bilo je uvođenje TQM-a (Total Quality Management) u niz knjižnica, i to zahvaljujući stručnjacima iz Velike Britanije, koji su putem tečajeva educirali mađarske knjižničare o tome kako identificirati i predstaviti pokazatelje o knjižničnoj djelatnosti te osigurati opstojnost knjižnica i u budućnosti. Također, danas je u Mađarskoj aktivna skupina knjižničara mlađe generacije posvećena toj problematici koja djeluje unutar stručnog tima mađarskoga Ministarstva kulture kako bi se tijekom vremena ponudila rješenja bolja od sadašnjih.

Ipak, i dalje najvažnije pitanje vezano uz knjižničnu statistiku ostaje ono o standardizaciji službene statistike o knjižničnoj djelatnosti, pri čemu je evidentan i nedostatak međunarodnih standarda koji bi se primjenjivali na globalnoj razini. Upravo o toj temi govorilo se i na 82. IFLA-inoj godišnjoj generalnoj konferenciji i skupštini održanoj 2016. godine u Columbusu (SAD), tijekom sastanaka IFLA-ine Sekcije za statistiku i vrednovanje. ${ }^{8}$ Zbog uočenih poteškoća na globalnoj razini, IFLA je za svoj cilj postavila izradu atlasa knjižnica cijeloga svijeta u bliskoj budućnosti ${ }^{9}$, pri čemu se najvećim dijelom kani oslanjati na suradnju s nacionalnim knjižničarskim udrugama i nacionalnim knjižnicama. ${ }^{10}$

\section{Zaključak}

Prikupljanje statističkih podataka o mađarskim knjižnicama vezuje se uz osnutak Središnjeg statističkog zavoda Mađarske i rad Károlya Keletija u drugoj polovini 19. stoljeća. U 20. stoljeću u prikupljanje podataka o knjigama, nakladničkoj i knjižničnoj djelatnosti uz Središnji statistički zavod Mađarske uključuje se i Nacionalna knjižnica Széchényi, koja od 1998. godine u svoje registre uključuje podatke svih javnih knjižnica u Mađarskoj.

\footnotetext{
8 Usp. Evaluating our worth : how can we quantify the value of libraries and information centers?: statistics and evaluation. // IFLA WLIC 13-19 August, Columbus, Ohio. [citirano: 201702-09]. Dostupno na http://www.ifla.org/node/10561.

9 Usp. Schrag, Tyler; Chris Mefford; Julia Cottrill; Jeremy Paley. Building a public library impact data hub : a global libraries „Data atlas” for storytelling, strategy development, and collaboration. // IFLA WLIC 18-21 August 2015, Cape Town, South Africa. [citirano: 2017-02-09]. Dostupno na http://library.ifla.org/1272/1/088-schrag-en.pdf.

10 Na spomenutim se sastancima IFLA-ine Sekcije za statistiku i vrednovanje nastojalo identificirati prepreke u uspostavi međunarodnih standarda za knjižničnu statistiku. Uz već poznate neusklađenosti, tijekom diskusije sudionici su utvrdili da čak i kod nacionalnih knjižnica statistički podaci o knjižničnoj djelatnosti nisu uvijek mrežno dostupni, dijelom i zbog toga što nacionalne knjižnice iz različitih zemalja ne djeluju prema istim standardima, i to posebice zbog toga što nemaju sve nacionalne knjižnice jedinstven knjižnični sustav, a u mnogim su zemljama njihove funkcije podijeljene među više nacionalnih knjižnica, a ponegdje i među više vrsta knjižnica (sveučilišne, narodne, specijalne i slično).
} 
No dok se u prošlom stoljeću smatralo da prikupljanje službene knjižnične statistike daje pozitivan učinak na osmišljavanje, planiranje, organiziranje i financiranje knjižnične djelatnosti u Mađarskoj, danas se upravo iz knjižnične prakse sve glasnije postavljaju pitanja stvarne svrhe i koristi od knjižnične statistike.

Više je razloga tomu: metodološki problemi, nedostatak standardizacije u definiranju pojmova, odabiru pokazatelja i prikupljanju podataka, nesuvremenost pokazatelja u odnosu na tehnološki okoliš, otvorenost interpretacije rezultata te vrlo važan izostanak vidljivog utjecaja aktivnosti prikupljanja i diseminacije statističkiih podataka na prisutnost i položaj knjižnica u mađarskom društvu.

Stoga knjižnična statistika u Mađarskoj treba revidirati svoju dosadašnju praksu, osuvremeniti i standardizirati metodologiju prikupljanja i obrade podataka te interpretaciju rezultata kako bi mogla poslužiti u svojoj danas najvažnijoj zadaći, a to je pronalaženje pravih načina za dokumentiranje knjižnične djelatnosti i njezina utjecaja na uspješnost društvenog i ekonomskog razvoja Mađarske.

\section{LITERATURA}

Cserta, Orsolya. A kulturális piac (ki)alakulása Magyarországon. // Statisztikai Szemle 5-6(2002). [citirano: 2017-02-09]. Dostupno i na http://www.ksh.hu/statszemle_archive/2002/2002_05-06/2002_05-06_577.pdf

European Commission. Cultural access and participation : Eurobarometer 79.2 : results for Hungary. Bruxelles, 2013. [citirano: 2017-02-09]. Dostupno na http://ec.europa. eu/commfrontoffice/publicopinion/archives/ebs/ebs_399_fact_hu_en.pdf

Hungary in figures : 2015. Budapest: Hungarian Central Statistical Office, 2016. [citirano: 2017-02-09]. Dostupno na http://www.ksh.hu/docs/hun/xftp/idoszaki/hif/hungary_in_figures_2015.pdf

Evaluating our worth : how can we quantify the value of libraries and information centers?: statistics and evaluation. // IFLA WLIC 13-19 August, Columbus, Ohio. [citirano: 2017-02-09]. Dostupno na http://www.ifla.org/node/10561

Libraries, archives (1990-) : STADAT [citirano: 2017-02-09]. Dostupno na https://www. $\mathrm{ksh} . \mathrm{hu} /$ docs/eng/xstadat/xstadat_annual/i_zkz002a.html

Magyar Statisztikai Évkönyv = Statistical Yearbook of Hungary : 2015. Budapest : Központi Statisztikai Hivatal, 2016.

Schrag, Tyler; Chris Mefford; Julia Cottrill; Jeremy Paley. Building a public library impact data hub : a global libraries „Data atlas” for storytelling, strategy development, and collaboration. // IFLA WLIC 18-21 August 2015, Cape Town, South Africa. [citirano: 2017-02-09]. Dostupno na http://library.ifla.org/1272/1/088-schrag-en.pdf 